\begin{tabular}{cc|c}
\hline & $\begin{array}{c}\text { Tarım Bilimleri Dergisi } \\
\text { Tar. Bil.Der. }\end{array}$ & Journal of Agricultural Sciences \\
& $\begin{array}{c}\text { Dergi web sayfası: } \\
\text { www.agri.ankara.edu.tr/dergi }\end{array}$ & $\begin{array}{c}\text { Journal homepage: } \\
\text { www.agri.ankara.edu.tr/journal }\end{array}$ \\
\hline
\end{tabular}

\title{
Influence of Stock on the Early Tree Growth, Yield and Fruit Quality Traits of Apricot (Prunus armeniaca L.)
}

\author{
Tomo MILOSEVIC ${ }^{\text {a }}$, Nebojsa MILOSEVIC ${ }^{\text {b }}$, Ivan GLISIC ${ }^{\text {a }}$ \\ ${ }^{a}$ University of Kragujevac, Faculty of Agronomy, Department of Fruit Growing and Viticulture, 32000 Cacak, Cara Dusana 34, SERBIA \\ ${ }^{b}$ Fruit Research Institute, Department of Pomology and Fruit Breeding, 32000 Cacak, Kralja Petra I/9, SERBIA
}

\section{ARTICLE INFO}

Research Article — Crop Production DOI: 10.1501/Tarimbil_0000001169

Corresponding author: Tomo MILOSEVIC, e-mail: tomom@tfc.kg.ac.rs, Tel: +381 32 303-400

Received: 05 May 2011, Received in revised form: 18 December 2011, Accepted: 21 December 2011

\begin{abstract}
This experiment was conducted in Cacak region (Western Serbia) in 2008-2010 to determine the effects of Myrobalan rootstock (Prunus cerasifera Ehrh.) and Blackthorn interstock (P. spinosa L.) on the tree growth, productivity and fruit quality traits of five apricot cultivars ( $P$. armeniaca L.) grown under dry, sandy-loam and acidic soil conditions. The orchard established in 2007 at a $5.5 \mathrm{~m} \times 3 \mathrm{~m}$ planting distance. The results showed that apricots grafted on Myrobalan appears to induce higher tree growth, yield (YI), cumulative yield (CY) and fruit weight (FW) when compared with the Blackthorn. Blackthorn showed a tendency to reduce a high vigour of apricot trees on Myrobalan, YI and fruit size. This interstock induced higher soluble solids/titratable acidity ratio (SS/TA ratio or RI) than Myrobalan. These results confirms the better adaptation of Myrobalan rootstock to dry, sandyloam and acidic soil than Blackthorn interstock.
\end{abstract}

Keywords: Acidic soil; Apricot; Fruit quality traits; Rootstock and interstock; Productivity

\section{Kayısının (Prunus armeniaca L.) Erken Ağaç Büyümesi, Verim ve Meyvenin Kalite Özelliklerine Anacının Etkisi}

\section{ESER BİLGISI}

Araștırma Makalesi — Bitkisel Üretim

Sorumlu Yazar: Tomo MILOSEVIC, e-posta: tomom@tfc.kg.ac.rs, Tel: +381 32 303-400

Geliş tarihi: 05 Mayıs 2011, Düzeltmelerin gelişi: 18 Aralık 2011, Kabul: 21 Aralık 2011

\section{ÖZET}

Bu çalışma, Myrobalan anacı (Prunus cerasifera Ehrh) ve Blackthorn ara anacının (P. spinosa L.) kıraç, kumlu ve asidik topraklarda yetiștirilen beș kayısı (P. armeniaca L.) çeşidinde büyüme, verim ve meyve kalitesine etkilerini belirlemek amacıyla, 2008-2010 yıllarında Batı Sırbistan'ın Cacak bölgesinde yapılmıştır. Bahçe $5.5 \mathrm{~m}$ x $3 \mathrm{~m}$ dikim aralığında 2007 yılında kurulmuştur. Myrobalan üzerine doğrudan ara anacı kullanmadan aşılı kayısılarda Blackthorn ara anacı kullanmaya göre daha kuvvetli büyüme, verim, kümülatif verim ve meyve ağırlığında artışlar gözlenmiştir. Blackthorn, ara anacının kayısı ağaçlarının doğrudan Myrobalan’a aşılamaya göre verim ve meyve 
boyutunda azaltma eğilimi gösterdiği belirlenmiştir. Bu ara anaç, Myrobalan’dan daha yüksek bir suda çözünebilir katı madde miktarı/titre edilebilir asitlik oranı beraberinde getirmiştir. Bu sonuçlara göre Myrobalan anacının doğrudan kullanılması, Blackthorn ara anacı kullanılması durumunda ağaçların kuru, killi kumlu ve asidik topraklara daha iyi adaptasyon göstermiştir.

Anahtar sözcükler: Asidik toprak; Kayısı; Meyvenin kalite özellikleri; Anaç ve ara anaç; Verimlilik

(C) Ankara Üniversitesi Ziraat Fakültesi

\section{Introduction}

The apricot $(P$. armeniaca L.) fruit is highly appreciated by consumers and is one of the most important fruit species grown in the world. The greatest amount of the world's apricot production comes from the countries around the Mediterranean Sea, that is, Turkey (Güner \& Gezer 2001) Spain, Italy, France, and Greece (Drogoudi et al 2008). Serbia has a great potential to produce many different kinds of fruits as a result of the wide variety of soil and environmental conditions. Apricot is one of them by 27 to 41 thousand tons yearly production (FAOSTAT 2011). The most important apricotgrowing area in Serbia is the Region of Cacak located in Western Serbia. However, the major factors limiting the intensive spread of apricot in Serbia include: blossoms killed by spring frosts, sudden (premature) wilting - Apoplexy, winter killing of flower buds prior to bloom, Plum pox virus infection in apricot trees and the absence of quality rootstock (Milošević et al 2010). On the other hand, in Region of Cacak, the most limiting edaphic factors are excessively dry, shallow, sandy-loam and acidic soils with a very low $\mathrm{pH}$. In these conditions, the most widely used rootstocks are Myrobalan seedlings ( $P$. cerasifera Ehrh.) and/or autochthonous plum cultivars belong to $P$. domestica L. ('Belošljiva', 'Petrovača') and $P$. insititia L. ('Trnošljiva'). For example, 'Belošljiva' had good soil adaptation, good graft compatibility, but problems of excessive suckering and Plum pox virus infection are limiting its use (Paunovic 1977).

The controversies regarding rootstocks for the apricot speak of the very complex nature of this problem and of the need to study it with a view to establishing the most suitable rootstocks for set and/or each apricot cultivar. In general, the rootstock provides the growth characteristics of the apricot tree (Hernández et al 2010), fruit size and fruit quality (Son \& Küden 2003), yield and yield efficiency (Egea et al 2004) and orchard system (Southwick \& Yeager 1999; Kapel 2003). Just as important is the role of interstock (Vachun 1983). However, few refer to the agronomic performance of adequate rootstocks (Egea et al 2004; Hernández et al 2010), especially of interstock, for apricot (Southwick \& Weis 1998; Djuric \& Keserovic 1999). Myrobalan seedlings are the most common rootstock in Serbian apricot orchards (Paunovic 1977), since the plum rootstocks are preferred for apricots in heavy and water logged soils (Güleryüz et al 1996). Additionally, apricot grafted on Myrobalan seedlings has a number of disadvantages, such as incompatibility, unstable yield, excessive vigour, nonuniform growth, early onset and late termination of the growing season, winter killing of blossom buds, frequent occurrence of apoplexy, susceptible to Pseudomonas ssp., and low yield (Crossa-Raynaud \& Audergon 1987). The numerous defects of Myrobalan are trying to eliminate or mitigate the use of other rotstocks and/or interstocks in some Serbian apricot orchards (Djuric \& Keserovic 1999). For example, data from literature indicated that Blackthorn as rootstock reduces tree vigour, and also induced precocity, cropping efficiency, frost hardy, possible tolerance to Pseudomonas ssp., wide soil adaptation, better fruit size and fruit colour (Southwick \& Weis 1998). Our hypothesis is that Blackthorn as interstock could exhibit the similar traits as mentioned above.

The present study was carried out over four years after planting with five apricot cultivars, grafted on Myrobalan rootstock and Blackthorn interstock, and grown on typical dry, shallow, sandy-loam and acidic soil conditions in the 
Cacak region (Western Serbia). The aim of this study was to evaluate the influence of above rootstock and/or interstock on the tree growth, precocity, yield performances and fruit quality attributes of five apricot cultivars.

\section{Materials and Methods}

\subsection{Plant material and field trial}

The three Serbian ('Aleksandar', 'Biljana' and 'Vera') and two introduced ('Harcot' and 'Roxana') apricot cultivars were evaluated during 2008 to 2010. Cultivars were grafted on Myrobalan seedlings and on Blackthorn interstock. Myrobalan is a high vigour plum species, whereas Blackthorn gave a low vigour tree. The cultivars were grafted directly on Myrobalan rootstock at $60 \mathrm{~cm}$ above ground level. The Blackthorn interstock were grafted onto Myrobalan stock at $20 \mathrm{~cm}$ above ground level, and the cultivars were grafted on interstocks at 60 $\mathrm{cm}$ above ground level. Myrobalan rootstock and Blackthorn interstock grafted onto Myrobalan stock showed good anchorage, although they expressed different vigour. The trial was conducted at an experimental orchard located in Prislonica near Cacak, Western Serbia $\left(43^{\circ} 53^{\prime} \mathrm{N}\right.$ latitude; $20^{\circ} 21^{\prime} \mathrm{E}$ longitude; $340 \mathrm{~m}$ altitude). The trees, spaced at $5.5 \mathrm{~m} \times 3 \mathrm{~m}$, were planted in 2007; training system was open vase. This training system controlled tree vigour by pruning in the summer. The orchard was managed following the usual standard procedures under non-irrigated practices. The experiment was established in a randomized block design with five trees for each stock-scion and stockinterstock-scion combination in four replicates. Tree growth, YI, YE and fruit quality traits were evaluated over three consecutive years (20082010), i.e. from second to fourth year after planting.

\subsection{Soil and weather conditions}

Soil in the trial was dry, shallow and acidic, with $1.68 \%$ organic matter, $0.16 \% \mathrm{~N}_{\mathrm{TOT}}, 178 \mathrm{mg} \mathrm{kg}^{-1}$ $\mathrm{P}_{2} \mathrm{O}_{5}, 220 \mathrm{mg} \mathrm{kg}^{-1} \mathrm{~K}_{2} \mathrm{O}, 0.39 \% \mathrm{CaO}, 6.2 \mathrm{mg} \mathrm{kg}^{-1}$ $\mathrm{MgO}$, and a sandy-loam texture. The soil $\mathrm{pH}$ in $0.01 \mathrm{M} \mathrm{KCl}$ was in the range from $4.86(0-30 \mathrm{~cm})$ to 4.33 (31-60 $\mathrm{cm}$ soil depth). In general, soil conditions were poor for normal vegetative and reproductive growth of apricot trees, as previously reported (Son \& Küden 2003).

The climate is maritime temperate or $\mathrm{Cfb}$ (Kottek et al 2006) with moderate to strong winters, and hot and semi to dry summers. In 2008 and 2010, the average air temperatures during calendar year were higher than normal refers, and lower in 2009 than the long-term average (Table 1). The average temperature for the growing season was much higher in 2008 and 2009, and lower in 2010 than the normal refers. Also, in all years, air temperatures in May, June and July were much higher than normal values. Total rainfall during year was much lower in 2008 and higher in 2009, especially in 2010, than the long-term period. Total rainfall for vegetative cycle was lower in 2008 and 2009, and higher in 2008 than the normal values, respectively (Table 1). The lack of rainfall before and during harvest period may have had a negative effect on the rate of some evaluated traits in the present study.

\subsection{Growth measurement and yield}

Trunk circumference was measured and calculated during the end of vegetative cycle 20 $\mathrm{cm}$ above the graft union, and the trunk crosssectional area (TCSA) was calculated $\left(\mathrm{cm}^{2}\right)$. YI per tree, CY and yield efficiency (YE) (ratio of final yield in $\mathrm{kg}$ per final TCSA in $\mathrm{cm}^{2}$ ) of each stock-scion and stock-interstock-scion combination were computed from the harvest data. All measurements were performed on five trees with four replicates for each stock-scion and stock-interstock-scion combination. The data are given in $\mathrm{kg}_{\text {tree }}^{-1}$ and $\mathrm{kg} \mathrm{cm}^{-2}$, respectively.

\subsection{Fruit quality traits}

FW was determined using a Tehnica ET-1111 technical scale (Iskra, Horjul, Slovenia) in 20 randomly selected fruits in four replicates for each stock-scion and stock-interstock-scion combination. The data are given as $\mathrm{g}$.

Fruit quality traits such as soluble solids content (SS), total sugars content (TS), titratable acidity (TA), SS/TA ratio or RI and flesh firmness 
Table 1-Monthly and growing season air temperature and rainfall for Cacak in 2008-2010 period Çizelge 1-2008-2010 döneminde Cacak bölgesinde görülen aylık ve yetiştirme dönemindeki hava sıcaklı̆̆ ve yağış miktarı

\begin{tabular}{|c|c|c|c|c|c|c|c|c|}
\hline \multirow[t]{2}{*}{ Month } & \multicolumn{4}{|c|}{$\begin{array}{l}\text { Air temperature, } \\
{ }^{\circ} \mathrm{C}\end{array}$} & \multicolumn{4}{|c|}{$\begin{array}{l}\text { Rainfall, } \\
\mathrm{mm}\end{array}$} \\
\hline & 2008 & 2009 & 2010 & $\mathrm{NR}^{1}$ & 2008 & 2009 & 2010 & $\mathrm{NR}^{1}$ \\
\hline January & 1.7 & 0.7 & 0.9 & 0.3 & 26.0 & 50.0 & 33.0 & 36.6 \\
\hline February & 5.5 & 2.6 & 3.0 & 2.3 & 8.0 & 32.0 & 52.0 & 30.7 \\
\hline March & 8.5 & 8.1 & 7.9 & 6.8 & 53.5 & 42.5 & 54.5 & 50.2 \\
\hline April & 13.7 & 14.8 & 13.3 & 11.5 & 35.5 & 12.5 & 52.0 & 33.3 \\
\hline May & 19.4 & 20.2 & 17.9 & 16.8 & 36.0 & 43.0 & 98.8 & 59.3 \\
\hline June & 23.3 & 21.4 & 21.3 & 20.0 & 79.0 & 98.4 & 81.0 & 86.1 \\
\hline July & 23.5 & 24.0 & 23.5 & 21.5 & 95.6 & 41.0 & 90.0 & 75.5 \\
\hline August & 25.3 & 24.7 & 23.7 & 21.2 & 36.0 & 35.5 & 78.5 & 50.0 \\
\hline September & 15.9 & 19.2 & 17.3 & 16.7 & 73.0 & 30.0 & 25.0 & 42.7 \\
\hline October & 14.0 & 11.6 & 10.0 & 11.4 & 30.5 & 91.5 & 63.0 & 61.7 \\
\hline November & 8.2 & 8.7 & 10.3 & 6.0 & 32.0 & 72.0 & 54.6 & 52.9 \\
\hline December & 4.9 & 3.7 & 1.8 & 1.4 & 36.0 & 97.0 & 37.0 & 56.7 \\
\hline $\begin{array}{l}\text { Mean or total for } \\
\text { year }\end{array}$ & 13.7 & 10.6 & 12.6 & 11.3 & 541.1 & 645.4 & 719.4 & 635.3 \\
\hline $\begin{array}{l}\text { Mean or total for } \\
\text { growing season }\end{array}$ & 19.3 & 19.4 & 16.5 & 17.0 & 385.6 & 351.9 & 488.3 & 408.6 \\
\hline
\end{tabular}

${ }^{1}$ NR: Normal refers to the long-term average (45-year average, i.e. 1965-2010 period)

(FF) were measured and calculated immediately after picking (commercial maturity stage). The SS $\left({ }^{\circ}\right.$ Brix) was determined at $20{ }^{\circ} \mathrm{C}$ with a Milwaukee MR 200 (ATC, Rocky Mount, USA) hand refractometer. The TS was determined using the Luff-Schoorl method and is expressed as percentage of fresh weight, while the TA was measured by neutralization to $\mathrm{pH} 7.0$ with $0.1 \mathrm{~N}$ $\mathrm{NaOH}$, and data are given as percentage of malic acid. On the basis of the measured data, SS/TA ratio (RI) was calculated. The FF was measured on opposite paired cheeks (where the skin was removed) using a Bertuzzi Penetrometer FT-327 (Facchini, Alfonsine, Italy) equipped with an 8$\mathrm{mm}$ cylindrical plunger. Data are given in $\mathrm{kg} \mathrm{cm}^{2}$.

\subsection{Data analysis}

Data obtained were statistically analyzed using two-way analysis of variance (ANOVA). The experiment had a 2 (stock) $\times 5$ (cultivar) factorial design. The treatment means were compared using LSD test at $P \leq 0.05$, using the MSTAT-C statistical computer package (Michigan State University, East Lansing, MI, USA). The figures are performed by the Statistica program (SPSS
Inc., SYSTAT version 6.0, Statistics, Chicago, IL, USA). The data are displayed as means \pm standard error $( \pm \mathrm{SE})$, and $P$ values less than 0.05 are considered statistically significant.

\section{Results and Discussion}

\subsection{Evaluation of tree growth, yield characteristics and fruit weight}

Tree vigour, as measured by TCSA, was significantly affected by the stocks and cultivars starting from the second year after planting (Table 2). Myrobalan produced significantly higher final TCSA value than Blackthorn for $28.60 \%$. The greatest final TCSA was observed in 'Biljana' and the lowest in 'Vera'; in the rest cultivars tree vigour was intermediate (Table 2). Additionally, on Myrobalan, the greatest TCSA was observed in 'Biljana' and lowest in 'Vera' (Figure 1a). In contrast, on Blackthorn, the lowest TCSA was registered in 'Biljana' and the highest in 'Harcot' (Figure 1b). This data show that trees of cultivars on Blackthorn grow more slowly than on Myrobalan rootstock (Crossa-Raynaud \& Audergon 1987), and being a less vigour interstock with a good capacity to control vigour 
Table 2-The influence of Myrobalan rootstock and Blackthorn interstock on tree vigour, cumulative yield, yield efficiency and fruit weight of five apricot cultivars, in the fourth (2010) year after planting Çizelge 2-Dikimin ardından dördüncü yılda Myrobalan anacı ve Blackthorn ara anacının beş kaylsı çeşidindeki ă̆aç büyümesi kümülatif verim, verim oranı ve meyve ă̆ırlı̆̆a etkisi

\begin{tabular}{|c|c|c|c|c|c|c|}
\hline Treatment & & TCSA, $\mathrm{cm}^{2}$ & $\begin{array}{l}\text { Yield, kg tree }{ }^{-1} \\
\text { Year - } 2010\end{array}$ & $\begin{array}{c}\text { Cumulative } \\
\text { yield, kg tree }{ }^{-1} \\
2008-2010\end{array}$ & $\begin{array}{l}\text { Yield efficiency, } \\
\mathrm{kg} \mathrm{cm}^{-2}\end{array}$ & Fruit weight, $g$ \\
\hline \multicolumn{7}{|l|}{ Stock (A) } \\
\hline Myrobalan & & $38.88 \pm 4.41 \mathrm{a}$ & $11.01 \pm 2.18 \mathrm{a}$ & $17.44 \pm 3.38 \mathrm{a}$ & $0.30 \pm 0.07 \mathrm{a}$ & $81.28 \pm 4.91 \mathrm{a}$ \\
\hline Blackthorn & & $27.76 \pm 1.22 b$ & $8.16 \pm 1.61 \mathrm{~b}$ & $12.76 \pm 2.53 b$ & $0.29 \pm 0.05 \mathrm{a}$ & $53.41 \pm 5.13 b$ \\
\hline \multicolumn{7}{|l|}{ Cultivar (B) } \\
\hline Aleksandar & & $31.38 \pm 3.33 \mathrm{c}$ & $9.83 \pm 1.46 b$ & $15.90 \pm 2.51 \mathrm{~b}$ & $0.31 \pm 0.01 \mathrm{ab}$ & $60.71 \pm 13.31 \mathrm{~d}$ \\
\hline Biljana & & $41.50 \pm 9.31 \mathrm{a}$ & $5.88 \pm 0.87 \mathrm{~d}$ & $8.89 \pm 1.33 \mathrm{e}$ & $0.16 \pm 0.04 b$ & $58.90 \pm 12.30 \mathrm{e}$ \\
\hline Vera & & $28.28 \pm 2.77 \mathrm{~d}$ & $6.58 \pm 0.98 \mathrm{c}$ & $10.35 \pm 1.78 \mathrm{~d}$ & $0.23 \pm 0.01 \mathrm{ab}$ & $61.68 \pm 17.78 \mathrm{c}$ \\
\hline Harcot & & $34.07 \pm 2.09 \mathrm{~b}$ & $9.06 \pm 1.35 \mathrm{~b}$ & $14.62 \pm 2.21 \mathrm{c}$ & $0.26 \pm 0.03 \mathrm{ab}$ & $69.89 \pm 12.56 \mathrm{~b}$ \\
\hline Roxana & & $31.37 \pm 3.28 \mathrm{c}$ & $16.56 \pm 2.46 \mathrm{a}$ & $25.71 \pm 3.86 \mathrm{a}$ & $0.52 \pm 0.02 \mathrm{a}$ & $85.52 \pm 13.72 \mathrm{a}$ \\
\hline \multicolumn{7}{|l|}{$\mathrm{A} \times \mathrm{B}$} \\
\hline \multirow{5}{*}{ Myrobalan } & Aleksandar & $34.72 \pm 2.89 \mathrm{c}$ & $11.30 \pm 1.07 \mathrm{c}$ & $18.41 \pm 2.67 \mathrm{c}$ & $0.32 \pm 0.02 \mathrm{a}$ & $74.02 \pm 8.89 \mathrm{~d}$ \\
\hline & Biljana & $57.81 \pm 4.33 \mathrm{a}$ & $6.76 \pm 0.88 \mathrm{~h}$ & $10.23 \pm 1.33 \mathrm{~h}$ & $0.12 \pm 0.01 \mathrm{a}$ & $71.20 \pm 9.13 \mathrm{e}$ \\
\hline & Vera & $31.06 \pm 1.81 \mathrm{f}$ & $7.56 \pm 1.10 \mathrm{~g}$ & $12.13 \pm 1.98 \mathrm{~g}$ & $0.24 \pm 0.02 \mathrm{a}$ & $79.46 \pm 8.23 \mathrm{c}$ \\
\hline & Harcot & $36.16 \pm 1.99 \mathrm{~b}$ & $10.41 \pm 1.41 \mathrm{~d}$ & $16.84 \pm 2.59 \mathrm{~d}$ & $0.29 \pm 0.03 \mathrm{a}$ & $82.45 \pm 9.11 \mathrm{~b}$ \\
\hline & Roxana & $34.65 \pm 1.34 \mathrm{~d}$ & $19.03 \pm 2.99 \mathrm{a}$ & $29.57 \pm 3.67 \mathrm{a}$ & $0.55 \pm 0.04 \mathrm{a}$ & $99.25 \pm 9.98 \mathrm{a}$ \\
\hline \multirow[t]{5}{*}{ Blackthorn } & Aleksandar & $28.05 \pm 2.45 \mathrm{~h}$ & $8.37 \pm 1.65 \mathrm{e}$ & $13.39 \pm 1.91 \mathrm{e}$ & $0.30 \pm 0.02 \mathrm{a}$ & $47.40 \pm 6.34 \mathrm{~g}$ \\
\hline & Biljana & $25.19 \pm 2.86 \mathrm{j}$ & $5.01 \pm 0.87 \mathrm{j}$ & $7.56 \pm 1.01 \mathrm{j}$ & $0.20 \pm 0.01 \mathrm{a}$ & $46.60 \pm 4.33 \mathrm{~g}$ \\
\hline & Vera & $25.51 \pm 2.09 \mathrm{i}$ & $5.60 \pm 0.89 \mathrm{i}$ & $8.57 \pm 1.34 \mathrm{i}$ & $0.22 \pm 0.01 \mathrm{a}$ & $43.90 \pm 5.19 \mathrm{~h}$ \\
\hline & Harcot & $31.98 \pm 2.87 \mathrm{e}$ & $7.71 \pm 0.99 \mathrm{f}$ & $12.41 \pm 1.72 \mathrm{f}$ & $0.24 \pm 0.02 \mathrm{a}$ & $57.33 \pm 7.76 \mathrm{f}$ \\
\hline & Roxana & $28.09 \pm 2.33 \mathrm{~g}$ & $14.10 \pm 1.73 b$ & $21.85 \pm 3.13 b$ & $0.50 \pm 0.04 \mathrm{a}$ & $71.80 \pm 8.13 \mathrm{e}$ \\
\hline \multicolumn{7}{|l|}{$\operatorname{LSD}_{0.05}$} \\
\hline Stock (A) & & 0.015 & 0.005 & 0.026 & 0.198 & 0.579 \\
\hline Cultivar (B) & & 0.024 & 0.008 & 0.041 & 0.313 & 0.915 \\
\hline $\mathrm{A} \times \mathrm{B}$ & & 0.033 & 0.035 & 0.058 & 0.443 & 1.295 \\
\hline
\end{tabular}

TCSA: trunk cross-sectional area; the same small letters in columns shows insignificant differences $(P \leq 0.05)$ by LSD test among cultivars.

under dry, sandy-loam and acidic soil conditions. Given the above, apricot trees grafted onto Blackthorn interstock can be planted at shorter distances apart, resulting in reduced vigour (Vachun 1983; Sadhu 1989; Southwick \& Weis 1998; Djuric \& Keserovic 1999). For this reason, high and semi high-density cultivation systems with Blackthorn interstocks can be valuable in apricot as it is the case in other fruit species. However, as the Cacak Region has insufficient irrigation water, seedling rootstocks should continue to be used in this area, as previously described by Paunovic (1977). Similar data reported Son \& Küden (2003).

In the first bearing year (2008), YI was very low, and there were no statistically significant rootstock and interstock differences (data not shown). However, in the next bearing years, especially in 2010 , differences between rootstock and interstock became evident, Myrobalan provided higher YI per tree for all cultivars than Blackthorn (Table 2). In that year, YI was also affected by the type of cultivar, being always greater in 'Roxana', and the smaller in 'Biljana'. This may be due to the fact that Afgan cultivar 'Roxana' adapted well to the soil and climatic conditions under Cacak Region, as previously found (Djuric \& Keserovic 1999). The lowest YI was produced by 'Biljana'. This is probably due to their high vigour and so high TCSA (Hernández et al 2010).

Myrobalan induced significantly higher CY 

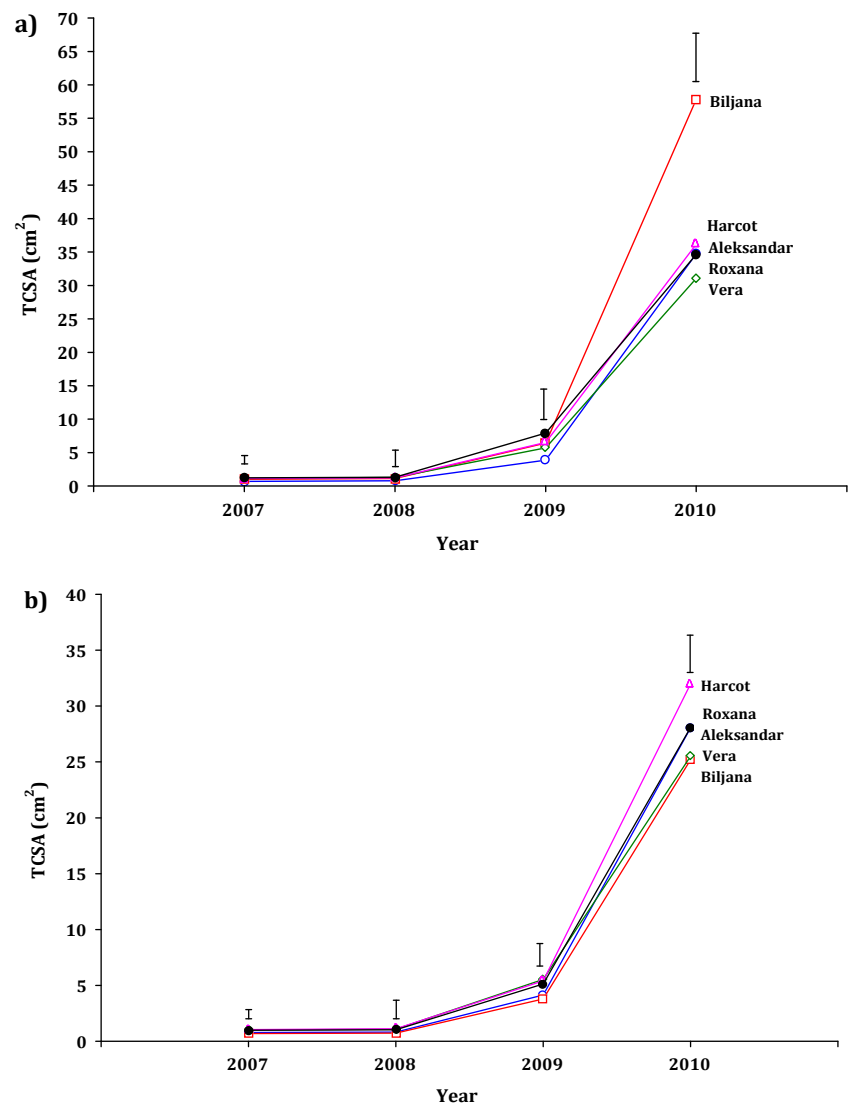

Figure 1-Myrobalan rootstock (a) and Blackthorn interstock (b) influence on trunk cross-sectional area (TCSA) of five apricot cultivars from the second (2008) to fourth (2010) year after planting. Vertical lines indicate $\mathrm{LSD}$ at $\boldsymbol{P} \leq \mathbf{0 . 0 5}$

Şekil 1-Dikimin ardından ikinci ve dördüncü yıllar arasında, Myrobalan anacı (a) ve Blackthorn ara anacının (b) beş kayısı çeşidindeki gövde enine kesitine etkisi. Dikey çizgiler $P \leq 0.05$ seviyesindeki LSD yi göstermektedir

than Blackthorn, whereas no significant differences in YE between them. By the fourth year after planting, the $\mathrm{CY}$ for all cultivars grafted on rootstock and interstock was greater in 'Roxana' (Table 2). The best YE were also found in 'Roxana', probably due to its higher YI and cumulative production. On the other hand, the lowest CY and YE were observed in 'Biljana'. Ondradu \& Scalas (1999) and Egea et al (2004) stated that some apricot cultivars grafted on Myrobalan gave the highest yield than other rootstocks. In contrast, some authors from different countries reported that cultivars on Myrobalan produced smaller yield then on apricot seedlings and/or on other rootstock for apricot (Loreti et al 2000; Son \& Küden 2003). The differences in data may be due to the results of genetic characteristic of rootstocks, interstocks, cultivars, cultural practices and climatic differences among years (Southwick \& Weis 1998; Singh et al 2010). 
Differences between rootstock and interstock for FW were statistically significant (Table 2). Myrobalan showed a higher mean FW than Blackthorn. The difference was $34.29 \%$ for all the evaluated cultivars. In the case of cultivars, the highest FW observed in 'Roxana' and the lowest in 'Biljana'. Kapel (2003) stated that the lower yields and smaller fruits of trees suggest that it should not be recommended as an apricot rootstock. Additionally, the early ripening cultivars 'Aleksandar', 'Biljana' and 'Vera' produced smaller fruits than late ripening 'Roksana' (Djuric \& Keserovic 1999). This seems to represent a major advantage for the growers. Previous work on apricot also reported a high variability among cultivars regarding this parameter (Mehlenbacher et al 1991; Asma \& Ozturk 2005; Hernández et al 2010).

Finally, significant interaction between stock and cultivar for all properties evaluated, except YE, was observed (Table 2) and indicates that apricot tree vigour, productivity and fruit size do not depend on particular parameter such as stock or cultivar, but on its combinations. In this context, Egea et al (2004) reported that interaction between apricot cultivars and rootstocks is presented as an interesting strategy for cultivar adaptation to different soil and climatic areas.

\subsection{Evaluation of fruit quality traits}

The values of major fruit quality traits for Myrobalan rootstock and Blackthorn interstock grafted with five apricot cultivars were presented in Table 3. Differences between rootstock and interstock for mean SS, TS, TA and FF values were little and insignificant. In the case of cultivars, the lowest SS was found in 'Roxana', and the highest value registered in 'Aleksandar'. From this point, all cultivars in both treatments showed SS values higher than $12{ }^{\circ}$ Brix. Some authors reported that apricot genotypes which have a SS content $>12{ }^{\circ}$ Brix, characterized by an excellent gustative quality (Egea et al 1994; Drogoudi et al 2008). Also, Ruiz \& Egea (2008) stated that SS is a very important quality attribute, influencing notably the fruit taste, whereas Daza et al (2008) reported that genotype has important effect on SS content, which was confirmed our results.

The lowest TS observed in 'Roxana' and the highest in 'Biljana' and 'Vera' (Table 3). Our range values are in agreement with previous works in apricot (Audergon et al 1990; Ruiz \& Egea 2008), but generally lower than those for a group of Turkish cultivars (Asma \& Ozturk 2005). The differences between the present results and those of the above authors were likely due to the different eco-geographical groups of apricot genotypes studied and environmental conditions.

The TA in apricot fruit was the greatest in 'Roxana', since the lowest TA exhibited in 'Vera' and 'Aleksandar' (Table 3). Hernández et al (2010) concluded that TA in apricot fruit was not significantly affected by the rootstock, which confirmed by results in our study. Some authors stated that fruit maturity stage at the harvest date is the principal factor affecting fruit acidity and also the SS content (Ruiz \& Egea 2008). In general, the range of TA values obtained in our study is in agreement with previous work in apricot (Drogoudi et al 2008; Demirtas et al 2010; Singh et al 2010).

Data in Table 3 showed that Blackthorn induced significantly higher mean SS/TA ratio or RI than Myrobalan. In the case of cultivars, the best RI was found in 'Aleksandar' and 'Vera', and the poorest in 'Roxana'. The relationship between SS and TA (RI) has an important role in consumer acceptance of some apricot, peach, nectarine and plum cultivars, as it has been previously mentioned (Crisosto et al 2004). Above authors also reported that in the case of cultivars with TA $>0.90 \%$ and $\mathrm{SS}<12.0 \%$, consumer acceptance was controlled by the interaction between TA and SS. In our study, Blackthorn induced better SS/TA ratio than Myrobalan. This result concurs with the findings of Sadhu (1989) and Southwick \& Weis (1998).

The FF was not significantly affected by the rootstock and/or interstock (Table 3). Nevertheless, none of the rootstock and/or interstock induced to firmness lower than $0.5 \mathrm{~kg}$ $\mathrm{cm}^{-2}$. Additionally, the highest FF was observed in 
Table 3-The influence of Myrobalan rootstock and Blackthorn interstock on fruit quality traits of five apricot cultivars in the fourth (2010) year after planting

Çizelge 3-Dikimin ardından dördüncü yılda Myrobalan anacı ve Blackthorn ara anacının beş kayısı çeşidindeki meyvenin kalite özelliklerine etkisi

\begin{tabular}{|c|c|c|c|c|c|c|}
\hline Treatment & & $\begin{array}{l}S S, \\
{ }^{\circ} \text { Brix } \\
\end{array}$ & $\begin{array}{c}T S, \\
\%\end{array}$ & $\begin{array}{c}T A, \\
\%\end{array}$ & $\begin{array}{c}\text { SS/TA ratio, } \\
R I \\
\end{array}$ & $\begin{array}{c}F F, \\
\mathrm{~kg} \mathrm{~cm}^{-2}\end{array}$ \\
\hline \multicolumn{7}{|l|}{ Stock (A) } \\
\hline Myrobalan & & $15.84 \pm 0.76 \mathrm{a}$ & $10.87 \pm 1.22 \mathrm{a}$ & $0.80 \pm 0.10 \mathrm{a}$ & $21.31 \pm 3.06 \mathrm{~b}$ & $1.78 \pm 0.17 \mathrm{a}$ \\
\hline Blackthorn & & $15.83 \pm 0.67 \mathrm{a}$ & $10.89 \pm 1.25 \mathrm{a}$ & $0.74 \pm 0.07 \mathrm{a}$ & $22.19 \pm 2.52 \mathrm{a}$ & $1.81 \pm 0.13 \mathrm{a}$ \\
\hline \multicolumn{7}{|l|}{ Cultivar (B) } \\
\hline Aleksandar & & $17.44 \pm 0.04 \mathrm{a}$ & $12.04 \pm 0.07 \mathrm{~b}$ & $0.62 \pm 0.01 \mathrm{~d}$ & $27.92 \pm 0.59 \mathrm{a}$ & $1.42 \pm 0.02 \mathrm{c}$ \\
\hline Biljana & & $16.07 \pm 0.07 \mathrm{c}$ & $13.06 \pm 0.04 \mathrm{a}$ & $0.71 \pm 0.02 \mathrm{c}$ & $22.65 \pm 0.53 \mathrm{c}$ & $2.07 \pm 0.04 \mathrm{a}$ \\
\hline Vera & & $16.08 \pm 0.08 \mathrm{c}$ & $12.98 \pm 0.02 \mathrm{a}$ & $0.61 \pm 0.03 \mathrm{~d}$ & $26.43 \pm 1.43 b$ & $2.12 \pm 0.09 \mathrm{a}$ \\
\hline Harcot & & $16.42 \pm 0.02 b$ & $9.75 \pm 0.06 \mathrm{c}$ & $0.86 \pm 0.07 \mathrm{~b}$ & $19.22 \pm 1.54 \mathrm{~d}$ & $1.89 \pm 0.01 \mathrm{~b}$ \\
\hline Roxana & & $13.16 \pm 0.19 \mathrm{~d}$ & $6.56 \pm 0.07 \mathrm{~d}$ & $1.05 \pm 0.06 \mathrm{a}$ & $12.53 \pm 0.95 \mathrm{e}$ & $1.47 \pm 0.13 \mathrm{c}$ \\
\hline \multicolumn{7}{|l|}{$\mathrm{A} \times \mathrm{B}$} \\
\hline \multirow{5}{*}{ Myrobalan } & Aleksandar & $17.49 \pm 0.99 \mathrm{a}$ & $11.97 \pm 1.33 \mathrm{e}$ & $0.64 \pm 0.02 \mathrm{def}$ & $27.33 \pm 1.87 \mathrm{a}$ & $1.40 \pm 0.02 \mathrm{e}$ \\
\hline & Biljana & $16.15 \pm 0.76 \mathrm{e}$ & $13.02 \pm 1.67 \mathrm{~b}$ & $0.73 \pm 0.03 \mathrm{de}$ & $22.12 \pm 1.47 \mathrm{c}$ & $2.04 \pm 0.08 b$ \\
\hline & Vera & $16.16 \pm 0.37 \mathrm{e}$ & $13.01 \pm 1.72 \mathrm{~b}$ & $0.58 \pm 0.01 \mathrm{f}$ & $27.86 \pm 1.94 \mathrm{a}$ & $2.22 \pm 0.09 \mathrm{a}$ \\
\hline & Harcot & $16.44 \pm 0.57 \mathrm{c}$ & $9.70 \pm 1.03 \mathrm{~g}$ & $0.93 \pm 0.04 b c$ & $17.68 \pm 1.13 \mathrm{e}$ & $1.90 \pm 0.11 \mathrm{c}$ \\
\hline & Roxana & $12.97 \pm 0.39 \mathrm{~h}$ & $6.63 \pm 0.98 \mathrm{~h}$ & $1.12 \pm 0.04 \mathrm{a}$ & $11.58 \pm 1.09 \mathrm{~g}$ & $1.34 \pm 0.08 \mathrm{e}$ \\
\hline \multirow[t]{5}{*}{ Blackthorn } & Aleksandar & $17.40 \pm 0.82 b$ & $12.11 \pm 1.49 \mathrm{~d}$ & $0.61 \pm 0.02 \mathrm{ef}$ & $28.52 \pm 2.02 \mathrm{a}$ & $1.44 \pm 0.04 \mathrm{e}$ \\
\hline & Biljana & $16.00 \pm 0.91 \mathrm{f}$ & $13.10 \pm 1.78 \mathrm{a}$ & $0.69 \pm 0.03 \mathrm{def}$ & $23.19 \pm 1.89 \mathrm{c}$ & $2.11 \pm 0.07 \mathrm{ab}$ \\
\hline & Vera & $16.00 \pm 0.84 \mathrm{f}$ & $12.96 \pm 1.64 \mathrm{c}$ & $0.64 \pm 0.01 \mathrm{def}$ & $25.00 \pm 1.96 \mathrm{~b}$ & $2.03 \pm 0.05 b$ \\
\hline & Harcot & $16.40 \pm 0.68 \mathrm{~d}$ & $9.81 \pm 1.13 \mathrm{f}$ & $0.79 \pm 0.04 \mathrm{~cd}$ & $20.76 \pm 1.82 \mathrm{~d}$ & $1.88 \pm 0.03 \mathrm{c}$ \\
\hline & Roxana & $13.35 \pm 0.49 \mathrm{~g}$ & $6.49 \pm 0.76 \mathrm{i}$ & $0.99 \pm 0.05 b$ & $13.48 \pm 1.11 \mathrm{f}$ & $1.61 \pm 0.07 \mathrm{~d}$ \\
\hline \multicolumn{7}{|l|}{$\operatorname{LSD}_{0.05}$} \\
\hline Stock (A) & & 0.023 & 0.006 & 0.072 & 0.603 & 0.055 \\
\hline Cultivar (B) & & 0.036 & 0.009 & 0.114 & 0.953 & 0.087 \\
\hline $\mathrm{A} \times \mathrm{B}$ & & 0.051 & 0.013 & 0.161 & 1.348 & 0.123 \\
\hline
\end{tabular}

Abbreviations: SS: soluble solids content; TS: total sugar content; TA: titratable acidity; SS/TA: ratio between soluble solids content and titratable acidity; for data analysis see Table 2 .

'Vera' and 'Biljana' and the lowest in 'Roxana' and 'Biljana'. Significant diferences among cultivars has been previously reported (Ruiz \& Egea 2008). According to Scandella et al (1998) the quality standards for apricot at harvest maturity, suitable for consumers and the apricot industry, are a firmness value between 3.0 and 0.5 $\mathrm{kg} \mathrm{cm}^{-2}$, which was confirmed our results.

Strong interaction between stocks and cultivars sugested that the levels of SS, TS, TA, RI and FF in cultivars were not mutualy proportional across stocks (Table 3). These observations also indicated that stocks in our trial does not seem to be a good indicator of above properties in apricot fruits because fruit maturity stage on the harvest date, air temperature and rainfall before harvesting could influence these variations, as previously obtained (Ruiz \& Egea 2008). For example, in 2008 and 2010 with high air temperatires and low rainfall before maturity (Table 1), SS, TS and RI values were higher than in 2009, whereas TA and FF values had adverse tendency (data not shown). Similar data has been previously reported (Audergon et al 1990; Crisosto et al 2004).

\section{Conclusion}

On dry, sandy-loam and acidic soil growing conditions, apricot trees grafted on Myrobalan rootstock appears to induce higher vigour, yield, cumulative yield and fruit weight whereas Blachthorn interstock showed higher value of ripening index. Yield efficiency, soluble solids, 
total sugars, titratable acidity and fruit firmness were similar in both treatments. In the case of cultivars, the more yield, cumulative yield, yield efficiency and fruit size was found in 'Roxana', whereas some major fruit quality traits was observed in 'Aleksandar' and 'Vera'. In general, only by long-term testing of above stocks on specific soils with desired cultivars can best choices be made.

\section{Acknowledgements}

This work is part of the 31064 project financially supported by the Ministry of Science of the Republic of Serbia. We express our sincerest gratitude to them for their support.

\section{References}

Asma B M \& Ozturk K (2005). Analysis of morphological, pomological and yield characteristics of some apricot germplasm in Turkey. Genetic Resources and Crop Evaluation 52: 305-313

Audergon J M, Souty M \& Breuils L (1990). Breeding for the production of high-quality apricots. In: La maîtrise de la qualité des fruits frais: Neuvième Colloque sur les Recherches Fruitières. Station de Recherches Fruitières Méditerranéennes, Avignon

Crisosto C H, Garner D, Crisosto G M \& Bowerman E (2004). Increasing 'Blackamber' plum (Prunus salicina Lindley) consumer acceptance. Postharvest Biology and Technology 34: 237-244

Crossa-Raynaud, P \& Audergon J (1987). Apricot rootstock. Rotstocks for fruit crops, pp. 295-320. Rom R C \& Carlson R F (Eds). John Wiley and Sons Inc., New York

Daza A, Garcia-Galavis P A, Grande M J \& Santamaria C (2008). Fruit quality parameters of 'Pioneer' Japanese plums produced on eight different rootstocks. Scientia Horticulturae 118: 206-211

Demirtas M N, Bolat I, Ercisli S, Ikinci A, Olmez H A, Sahin M, Altindag M \& Celik B (2010). The effect of different pruning treatments on the tree growth, fruit quality and yield of 'Hacihaliloglu' apricot. Acta Scientarum Polonorum, Hortorum Cultus 9: 183-192

Djuric B \& Keserovic Z (1999). Study on the possibilities of use of black thorn (Prunus spinosa L.) as an interstock in apricot. Acta Horticulturae 488: $533-538$
Drogoudi P D, Vemmos S, Pantelidis G, Petri E, Tzoutzoukou C \& Karayiannis I (2008). Physical characters and antioxidant, sugar, and mineral nutrient contents in fruit from 29 apricot (Prunus armeniaca L.) cultivars and hybrids. Journal of Agricultural and Food Chemistry 56: 10754-10760

Egea J, García J E \& Berenguer T (1994). Variedades de albaricoquero. Hortofruticultura 6: 56-62

Egea J, Ruiz D \& Martínez-Gómez P (2004). Influence of rootstock on the productive behaviour of 'Orange Red' apricot under Mediterranean conditions. Fruits 59: $367-373$

FAOSTAT (2011). FAO Statistics Division, May 29, 2011. Available from http://faostat.fao.org

Güleryüz M, Bolat İ, Pirlak L, Eşítken A \& Ercíşlí S (1996). Investigations on determination of nutritional status of apricot (cv. Hasanbey) grown in Erzincan. Turkish Journal of Agriculture and Forestry 20: 479-487

Güner M \& Gezer I (2001). Kayısı hasatında bir el silkeleyicinin bazı parametrelerinin belirlenmesi. Tarım Bilimleri Dergisi 7: 5-8

Hernández F, Pinochet J, Moreno M A, Martínez J J \& Legua P (2010). Performance of Prunus rootstocks for apricot in Mediterranean conditions. Scientia Horticulturae 124: 354-359

Kapel F (2003). Influence of pruning and interspecific Prunus hybrid rootstocks on tree growth, yield and fruit size of apricot. Journal of the American Pomological Society 57: 100-106

Kottek M J, Grieser C, Beck B, Rudolf B \& Rubel F (2006). World map of the Köppen-Geiger climate classification updated. Meteorologische Zeitschrift 15: $259-263$

Loreti F, Massai R, Fei C \& Cinelli F (2000). Bioagronomic behavior of several apricot rootstocks on the Tuscany coast. Rivista Frutticoltura $e$ Ortofloricoltura 62: 69-73

Mehlenbacher S A, Cociu V \& Hough L F. 1991. Apricots (Prunus). Genetic resources of temperate fruit and nut crops, pp 65-107. Moore J N \& Ballington J R (Eds). International Society for Horticultural Science, Wageningen

Milošević T, Milošević N, Glišić I \& Krška B (2010). Characteristics of promising apricot (Prunus armeniaca L.) genetic resources in Central Serbia based on blossoming period and fruit quality. Horticultural Science 37: 46-55

Ondradu G \& Scalas B (1999). Vegeto-productive behavior of $\mathrm{S}$. Castrese and Trynthos grafted on 
several rootstocks. Italus Hortus 6: 74-75

Paunovic A S (1977). Species, cultivars, rootstocks and environment. EPPO Bulletin 7: 11-28

Ruiz D \& Egea J (2008). Phenotypic diversity and relationships of fruit quality traits in apricot (Prunus armeniaca L.) germplasm. Euphytica 163: $143-158$

Sadhu M K (1989). Stock-scion relationship. Plant propagation, pp 184-191. New Age International (P) Ltd. (Eds), New Delhi

Scandella D, Sibille I, Venien S, Lichou J \& Jay M (1998). Abricot: Evaluation des atouts organoleptiques. Infos-Ctifl 141: 22-25

Singh V J, Sharma S D, Kumar P, Bhardwa S K \& Raj $\mathrm{H}$ (2010). Conjoint application of bio-organic and inorganic nutrient sources for improving cropping behaviour, soil properties and quality attributes of apricot (Prunus armeniaca). Indian Journal of Agricultural Sciences 80: $981-987$

Son L \& Küden A (2003). Effects of seedling and GF31 rootstocks on yield and fruit quality of some table apricot cultivars grown in Mersin. Turkish Journal of Agriculture and Forestry 27: 261-267

Southwick S M \& Weis K G (1998). Selecting and propagating rootstocks to produce apricots. HortTechnology 8: 164-170

Southwick S M \& Yeager J T (1999). Effect of rootstock, cultivar and orchard system on apricot production. Acta Horticulturae 488: 483-488

Vachun Z (1983). Influence of interstock apricot cultivars on the growth and crop yield of the Velkopavlovicka apricot. Acta Horticulturae 121: 289-294 